\title{
Potensi Cadangan Panas Bumi dengan Metoda Volumetrik Pada Sumur Saka-1 Lapangan Panas Bumi “ $X$ ” Kabupaten Lembata NusaTenggara Timur
}

\author{
Sari Wulandari Hafsari ${ }^{1}$, Akhmad Rading ${ }^{2}$ \\ ${ }^{1}$ Staf Pengajar Prodi Teknik Perminyakan Universitas Proklamasi 45 Yogyakarta, Teknik Perminyakan \\ ${ }^{2}$ Dinas Pertambangan (ESDM) Kabupaten Lembata, NTT \\ Coresponding author.Email : swulandarihafsari@yahoo.com
}

\begin{abstract}
Abstrak
Secara geologi Indonesia berada di zona Sabuk Api atau busur vulkanik yang merupakan produk konvergensi berupa subduksi antara lempeng Samudra Hindia-Australia dengan lempeng benua Asia berdasarkan konsep Tektonik lempeng. Potensi Panas bumi Indonesia tercatat sebagai yang terbesar ketiga di dunia dengan potensi cadangan 40\%, Direktorat Inventarisasi Sumber Daya Mineral (ESDM) mengidentifikasi 256 daerah panas bumi dengan total potensi mencapai atau sekira 28.617 MW Penggunaan potensi panas bumi Indonesia hingga Tahun 2016 baru mencapai 4\% atau sekira 1341 MW sehingga masih perlu ditingkatkan. Target pemerintah tentang kebijakan Energi Nasional terkait penggunaan energi terbarukan sebesar 25\% pada tahun 2015, memicu peningkatan kegiatan pencarian dan eksplorasi panas bumi.
\end{abstract}

Penyelidikan Direktorat Inventarisasi ESDM (2006) di Kabupaten Lembata, Nusa Tenggara Timur mencatat tiga lapangan potensi panas bumi yakni : Atadei, Roma dan Adum. Sumber panas bumi umumnya berasosiasi dengan gunungapi menjelang padam maupun masih aktif. Syarat terbentuknya panas bumi adalah adanya sumber panas (magma), batuan reservoir, batuan penudung dan akuifer. Hasil inventarisasi dan eksplorasi. Tulisan ini difokuskan pada perhitungan cadangan yakni energi panas bumi yang kenyataannya dapat diambil dan potensi listrik yang dapat dibangkitkan pada lapangan panas bumi X Kabupaten Lembata, Nusa Tenggara Timur. Tahapan awal dari upaya untuk mengetahui potensi energi panas bumi dimulai dari eksplorasi terencana dan terpadu yang meliputi kegiatan survey geologi, geokimia, geofisika, landaian suhu dan pemboran uji/eksplorasi panas bumi yang diakhiri dengan kegiatan pemboran sumur produksi serta pembangkit power plant untuk listrik jika hasil pemboran uji memberikan gambaran yang positif serta faktor kebutuhan akan energi/listrik.

Cadangan energi panas bumi yang kenyataannya dapat diambil di Lapangan panas bumi X adalah 3,94 x $10^{11} \mathrm{KJ}$ dan besarnya potensi listrik yang dapat dibangkitkan adalah sebesar 41 Mwe Sehingga Lapangan panas bumi X prospek dan layak untuk dikembangkan sebagai Pembangkit Listrik Tenaga Panas Bumi (PLTP), sehingga kebutuhan listrik masyarakat Kabupaten Lembata sebesar 5 Mwe dapat terpenuhi.

Keywords: volumetric, eksplorasi panas bumi, potensi listrik

\section{Pendahuluan}

Akibat dari proses gunung api terbentuk sumber panas bumi yang membentuk sistem panas bumi dan dipengaruhi oleh proses-proses geologi yang sedang atau telah berlangsung disepanjang jalur gunung api tersebut, sehingga memungkinkan terbentuknya suatu lapangan panas bumi yang potensial untuk diproduksikan. Syarat-syarat umum terbentuknya potensi panas bumi adalah adanya sumber panas (magma), batuan reservoir (reservoir rock), batuan penudung (cap rock) dan aquifer.

\subsection{Letak Geografis Lapangan Panas Bumi $X$}

Lapangan Panas Bumi X secara administrasi termasuk dalam wilayah Kabupaten Lembata, Propinsi Nusa Tenggara Timur. Luas wila yah Kabupaten Lembata 1.266,39 km persegi, kira-kira sepertiga puluh tu juh dari total luas daratan Nusa Tenggara Timur (Luas NTT 47.349,90 $\mathrm{Km}^{2}$ ), Lihat Gambar 1.

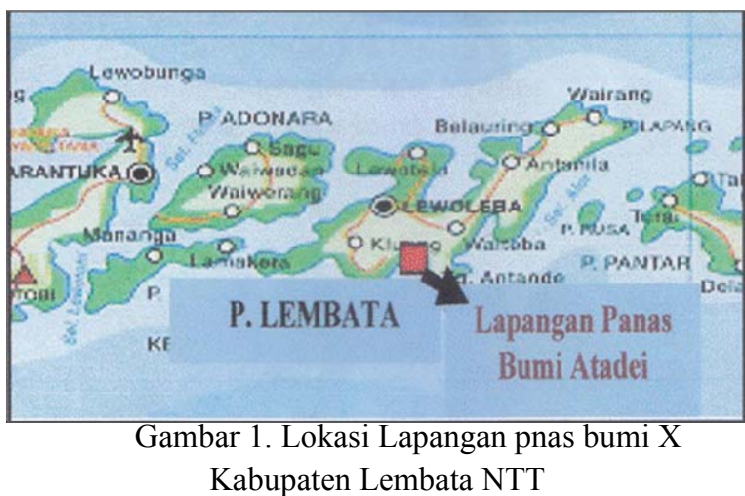

1.2. Geologi Lapangan Panas Bumi " $X$ ”

Sundhoro dkk, 1997, 2000, membagi daerah panas bumi X ini menjadi beberapa satuan batuan yang terdiri dari aliran lava dan endapan piroklastik yang berasal dari beberapa pusat erupsi yaitu dari Ile Kewiki, Ile Watulolo, Ile Mauraja, Ile Watuwawer, Ile Bauraja, Ile Guakerada, Ile Kedang, Ile Lamakeba dan Ile Benolo, Karangora, dan Atalojo, juga terdapat kubah lava Ile Kimo, ditunjukkan pada Gambar 2. 


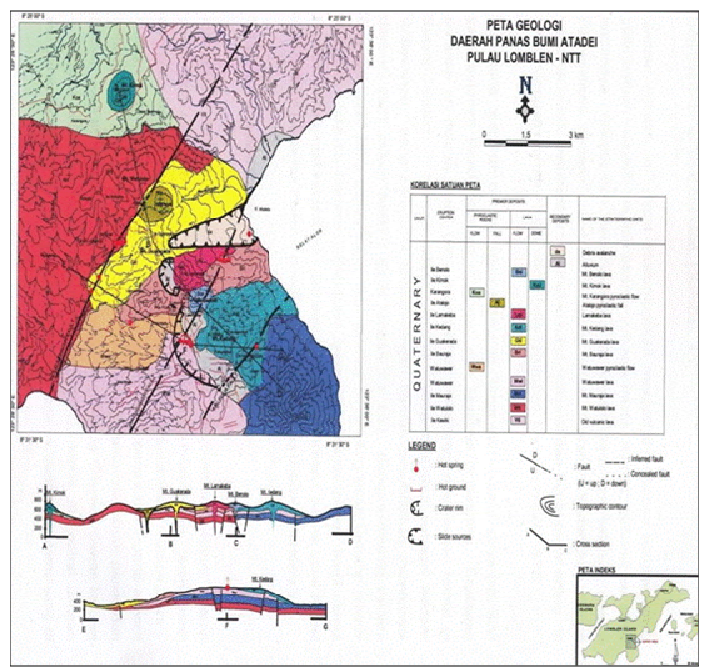

Gambar 2. Peta Geologi Lapangan panas bumi X Kabupaten Lembata NTT

Stratigrafi daerah ini di susun berdasarkan hubungan relatif masing-masing unit yang penamaan-nya di dasarkan pada pusat erupsi dan genesanya, dikelompokkan menjadi 2:

1.Kelompok batuan volkanik tua, terdapat disebelah barat dan timur laut, berupa aliran lava, piroklastik dan endapan lahar dengan tingkat pelapukan lanjut.

2.Kelompok batuan vulkanik muda yang membentuk kerucut - kerucut gunungapi sepanjang garis kelurusan

berarah hampir utara selatan dengan ketinggian antara 200 sampai $300 \mathrm{~m}$ dari dataran di sekitarnya, umumnya terdiri dari lava andesit.

Struktur di tandai dengan kelurusan pusatpusat erupsi teramati jelas dari foto udara yang memanjang dari utara (Ile Kimok) ke selatan (Ile Werung dan Hobal) dengan membentuk arah utarabarat laut/selatan-tenggara (NNW-SSE). Struktur ini adalah struktur besar tertua yang di-perkirakan memotong hingga basemen, yang mengontrol vulkanisme di Pulau Lembata khususnya daerah "X" pada dimana sepanjang kelurusan ini telah muncul rang-kaian gunung api, diantaranya adalah G. Mauraja, G. Gua-kerada, G. Atalojo, G. Kedang,. G. Lamakeba G. Benolo, G. Kimok, G.Ile Werung dan G. Hobal (Gambar 2).

\subsection{Manifestasi Panas Bumi}

Pemunculan manifestasi panas bumi di daerah ini dikontrol oleh struktur geologi sesar maupun struktur kaldera seperti: 1) Sesar Mauraja berarah timurlaut-baratdaya, manifestasi panas bumi Lewogeroma dan Waiketi, 2) Sesar Waibana, berarah baratlaut-tenggara mengontrol pemunculan mani-festasi panas bumi Wai Kowan dan Wai Kerata, dan 3) Sesar Watuwawer, berarah timur laut-baratdaya sebagai pengontrol pemunculan manifestasi panas bumi Lewo Kebingin (Koru Lewo Kebingin) berupa pemunculan fumarola, tanah panas, batuan ubahan dan mata air panas Wai Kowan

\subsection{Prospek Panas Bumi}

Prospek panas bumi " $X$ " ditandai oleh manifesti panas bumi yang hadir berupa mata air panas, kolam air panas, tanah panas, fumarol, kubangan lumpur dan batuan alte-rasi, yang kemudian dikelompokan berdasarkan lokasinya. Selanjutnya, (Fredy dkk, 2002), melakukan rekonstruksi pola struktur geologi yang dikombinasikan dengan pemun culan manifesttasi panas bumi permukaan, adanya anomali geokimia (Hg dan $\mathrm{CO} 2$ ), data geolistrik dan hasil pemboran sumur dangkal, temperature rendah. Penampang rekonstruksi struktur tersebut ditarik dari arah barat laut-tenggara berdasarkan hasil penyelidikan geologi (Herry dkk, 1997, 2000) dan dari penampang ini dapat terlihat arah sumber panas, batas atas/top reservoir dan kontrol struktur yang mungkin dijadikan target kedalaman dalam pemboran eksplorasi/semi eksplorasi.

\subsection{Karakteristik Reservoir Panas Bumi}

Batuan reservoir panas bumi sepenuhnya dipengaruhi oleh aspek - aspek kejadian alam dan geologi sebelumnya. Jenis batuan reservoir panas bumi dikelompokan dalam tiga jenis yaitu batuan beku, sedimen dan metamorf.

Batuan reservoir panas bumi biasanya adalah batuan beku, tersusun atas $\mathrm{Si}, \mathrm{Fe}, \mathrm{Mg}, \mathrm{Na}$, $\mathrm{Ca}$ dan $\mathrm{K}$ bersama sejumlah kecil Ti, Mn dan $\mathrm{P}$. Elemen tersebut didampingi oleh oksigen dan sejumlah batuan dalam bentuk komponen oksida $\left(\mathrm{Al}_{2} \mathrm{O}_{3}, \quad \mathrm{SiO}_{2}\right)$. Hasil analisis kimia batuan reservoir pada lapangan panas bumi menunjukan bahwa kandungan $\mathrm{SiO}_{2}$ berkisar antara $35-75 \%$; dan $\mathrm{Al}_{2} \mathrm{O}_{3}$ sekitar 12 - 18\% yang mencapai $20 \%$ pada batuan beku intermediet. Untuk kadar $\mathrm{SiO} 2$ rendah, kandungan $\mathrm{FeO}, \mathrm{Fe}_{2} \mathrm{O}_{3}, \mathrm{MgO}$ dan $\mathrm{CaO}$ 
berkisar antara $20-30 \%$, sedangkan batuan beku kadar $\mathrm{SiO}_{2}$ tinggi kandungan $\mathrm{FeO}, \mathrm{Fe}_{2} \mathrm{O}_{3}, \mathrm{MgO}$ dan $\mathrm{CaO}$ berkisar $5 \%$. Batuan beku bersifat alkali (intermediate conten) memiliki kandungan $\mathrm{Na}_{2} \mathrm{O}$ lebih dari $8 \%$ dan $\mathrm{K}_{2} \mathrm{O}_{6}$ jarang mencapai $10 \%$.

\subsection{Sifat Fisik Batuan Reservoir}

Sifat fisik batuan reservoir panas bumi:

\section{Porositas,}

Prositas adalah kemampuan untuk menyimpan air atau uap air. Porositas diklasifikasikan menjadi :

a. Porositas primer, terjadi selama proses pengendapan berlangsung.

b. Porositas sekunder, terbentuk karena proses geologi setelah pengendapan. Porositas sekunder umumnya dijumpai pada reservoir panas bumi, berupa rekahan-rekahan (fracture). Rekahan-rekahan tersebut tidak beraturan, sehingga derajat keseragamannya rendah, dan umumnya dikelilingi matrik yang memiliki porositas rendah, seperti pada batuan beku.

Dalam teknik reservoir, didefinisikan sebagai fraksi atau persen. Porositas dibagi menjadi:

a. Porositas total, yaitu perbandingan antara volume ruang kosong seluruhnya dengan volume total batuan.

b. Porositas efektif, yaitu perbandingan antara volume ruang kosong yang saling berhubungan dengan volume total batuan.

Kenyataannya, pada sistem panas bumi harga porositas rata-rata sekitar $5-30 \%$.

\section{Permeabilitas}

Permeabilitas adalah kemampuan batuan untuk mengalirkan fluida. Permeabilitas dibedakan menjadi :

a. Permeabilitas absolute, untuk fluida yang mengalir satu fasa (air atau uap saja).

b. Permeabilitas efektif, untuk fluida yang mengalir lebih dari satu fasa. Permeabilitas efektif, untuk fluida yang mengalir lebih dari satu fasa.

Untuk reservoir panas bumi, biasanya permeabilitas vertikal sekitar $10-14 \mathrm{~m}^{2}$, dan permeabilitas horizontal dapat mencapai 10 kali lebih besar

\section{Kompresibilitas batuan}

Kompresibilitas batuan adalah perubahan volume akibat perubahan tekanan per-satuan volume.

Tekanan dibagi menjadi dua tekanan yaitu:

a. Tekanan dalam, yaitu tekanan hidrostatik fluida dalam pori-pori batuan.

b. Tekanan luar, yaitu beban batuan yang ada diatasnya (overburden pressure).

Kompresibilitas batuan dibedakan menjadi:

1. Kompresibilitas matriks batuan, $\mathrm{Cr}$
2. Kompresibilitas bulk batuan, $\mathrm{Cb}$

3. Kompresibilitas pori-pori, $\mathrm{Cp}$

\section{Spesifik Panas Batuan.}

Spesifik panas bumi adalah jumlah energy panas yang diperlukan untuk menaikan temperature $1^{\mathrm{OC}}$ tiap unit massa material.

\section{Konduktifitas Panas Batuan,}

Konduktifitas panas batuan adalah besarnya kemampuan batuan untuk menghantarkan energi panas yang dipengaruhi oleh dien thermal, dengan satuan $\mathrm{W} /\left(\mathrm{m}^{\circ}{ }^{\mathrm{oK}}\right)$. Harga konduktifitas panas batuan umumnya adalah 2 $2,5 \mathrm{~W} / \mathrm{m} .^{\circ \mathrm{K}}$.

\section{Densitas Batuan}

Densitas adalah perbandingan antara berat batuan terhadap volume. Densitas batuan lapangan panas bumi umumnya berbanding lurus dengan heat content semakin besar densitas batuan tersebut.

\subsection{Sifat Fisik Fluida Reservoir}

Dalam teknik reservoir panas bumi, terdapat dua fluida yaitu air dan uap air. Sifat-sifat fisik fluida reservoir adalah:

1. Densitas fluida, Satuan densitas adalah massa volume, biasanya $\mathrm{kg} / \mathrm{m}^{3}$.

2. Spesifik volume, satuan spesifik volume uap dan cairan adalah $\mathrm{m}^{3} / \mathrm{kg}$.

3. Konduktifitas panas fluida, adalah kemampuan mineral untuk memindahkan energi panas secara konduktif yang dipengaruhi oleh gradien termal-nya, dengan satuan $\mathrm{W} / \mathrm{m} .^{\circ \mathrm{K}}$.

4. Viskositas, viskositas fasa cair dan uap dipengaruhi oleh senyawa kimia terlarut $(\mathrm{NaCl}, \mathrm{KCl}$ dan $\mathrm{CaCl})$, dan sedikit bervariasi terhadap tekanan.

5. Energi dalam, adalah ukuran banyaknya panas yang terkandung didalam suatu material persatuan massa, energi dalam spesifik untuk uap dan liquid biasanya dinyatakan sebagai Uv, dan $\mathrm{U}_{1}$.

6. Kapasitas panas, adalah ukuran banyaknya energi panas yang diperlukan untuk menaikan $1^{\mathrm{OC}}$ tiap unit massa material.

7. Konversi listrik, adalah perubahan energi termal menjadi energi listrik dengan asumsi menurut temperature dalam reservoir dengan notasi $\eta$ (fraksi).

8. Faktor Rekoveri, adalah persentase dari jumlah fluida panas bumi yang dapat diekstrak ke permukaan.

9. Potensi reservoir panas bumi, adalah besarnya energi yang tersimpan. 


\subsection{Klasifikasi Potensi Panasbumi}

Berdasarkan Standar Nasional Klasifikasi Potensi Energi Panas Bumi di Indonesia tahun 1999, No. SNI 03 - 5012 - 1999, potensi energi panas bumi di Indonesia dibagi menjadi 5 (lima) kelas dimulai dari :

1.Sumber daya Spekulatif

2. Sumber daya Hipotetis,

3. Cadangan Terduga,

4.Cadangan Mungkin,

5.Cadangan Terbukti (kelas tertinggi).

\subsection{Klasifikasi Sumber Daya}

Sumber daya panas bumi dibagi dua kelas:

1. Kelas Sumber Daya Spekulatif, adalah potensi yang besar energinya didasarkan pada studi literatur atau penyelidikan pendahuluan.

2. Kelas Sumber Daya Hipotetis, adalah besarnya energi yang tersimpan pada suatu daerah setelah diperkirakan dengan ilmu kebumian atau pengujian sumur.

\subsection{Klasifikasi Cadangan}

Cadangan panas bumi di klasifikasikan menjadi tiga kelas:

1. Kelas Cadangan Terduga, dimana estimasi potensi energinya didasarkan pada hasil penyelidikan rinci.

2. Kelas Cadangan Mungkin, estimasi potensi energi didasarkan pada hasil penyelidikan rinci dan telah diindentifikasi dengan bor eksplorasi (wildcat) serta hasil pra-studi kelayakan.

3. Kelas Cadangan Terbukti, estimasi potensi energinya didasarkan pada hasil penyelidikan rinci, diuji dengan sumur eksplorasi, delineasi dan pengembangan serta dilakukan studi kelayakan.

\section{Metodologi}

\subsection{Metode Estimasi Sumber Daya dan Potensi Energi Panas Bumi.}

Metode volumetrik umumnya digunakan untuk estimasi potensi energi panas bumi pada kelas sumber daya hipotesis sampai dengan cadangan terbukti. Dua model pendekatan yang digunakan yaitu :

1. Model pendekatan dengan asumsi parameter reservoir yang seragam (lumped parameter model).

2. Model pendekatan dengan asumsi parameter reservoir yang heterogen (distributed parameter model).

\subsection{Angka Parameter dalam Estimasi Potensi Panas Bumi.}

Pada kelas sumber daya hipotetis sampai dengan cadangan terbukti digunakan metode volumetrik dengan rumus:

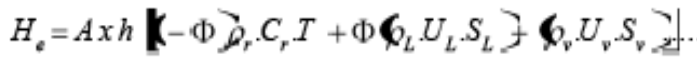

$\mathrm{He}$ : kandungan energi panas $(\mathrm{kJ})$

A : luas daerah panas bumi prospek $(\mathrm{km} 2)$

$\mathrm{h}$ : tebal reservoir $(\mathrm{m})$

$\mathrm{T}$ : temperatur reservoir $\left({ }^{\circ} \mathrm{C}\right)$

$\mathrm{S}_{\mathrm{L}}$ : saturasi air (fraksi)

$\mathrm{S}_{\mathrm{V}}$ : saturasi uap (fraksi)

$\mathrm{U}_{\mathrm{L}}$ : energi dalam air $(\mathrm{kJ} / \mathrm{kg})$

$\mathrm{U}_{\mathrm{V}}$ : energi dalam uap $(\mathrm{kJ} / \mathrm{kg})$

$\varnothing$ : porositas batuan reservoir (fraksi)

cr : kapasitas panas batuan $\left(\mathrm{kJ} / \mathrm{kg}{ }^{\circ} \mathrm{C}\right)$

$\rho_{1}:$ densitas batuan $(\mathrm{kg} / \mathrm{m} 3)$

$\rho_{2}$ : densitas air $(\mathrm{kg} / \mathrm{m} 3)$

$\rho_{3}$ : densitas uap $(\mathrm{kg} / \mathrm{m} 3)$

Dengan prosedur sebagai berikut :

1. Menghitung kandungan energi di dalam reservoir pada keadaan awal (Ti) :

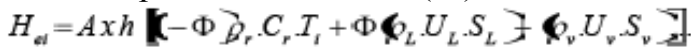

2. Menghitung kandungan energi di dalam reservoir pada keadaan akhir(Tf)

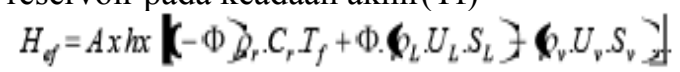

3. Energi maksimum yang dimanfaatkan :

$$
H_{\text {th }}=H_{\text {el }}-H_{\text {ef }}
$$

4. Energi panas yang kenyataannya dapat di ambil (cadang-

an panas bumi), jika cadangan dalam satuan $\mathrm{KJ}$.

Maka besar cadangan ditentukan sebagai berikut;

$$
H_{d e}=R_{f}-H_{\text {th }} \text {. }
$$

Dimana :

$R f=\frac{T l-T f}{T l-T g} \times 1$

Jika cadangan dinyatakan dalam satuan MWth dengan Formula :

$H_{\text {twermal }}=\frac{H_{d e}}{t \times 365 \times 24 \times 3600}$

5. Menghitung besarnya potensi listrik panas bumi, yaitu besarnya energi listrik yang dapat dibangkitkan selama periode waktu $t$ tahun (dalam satuan MWe).

$$
H_{e l}=\frac{H_{d s} \cdot \eta}{t \times 365 \times 24 \times 3600} .
$$


Dimana :

$\mathrm{T}_{\mathrm{i}}: \quad$ temperatur awal $\left({ }^{\circ} \mathrm{C}\right)$

$\mathrm{T}_{\mathrm{f}}: \quad$ temperatur akhir $\left({ }^{\circ} \mathrm{C}\right)$

Ts : $\quad$ temperatur permukaan $\left({ }^{\circ} \mathrm{C}\right)$

$\mathrm{H}_{\mathrm{ei}}$ : kandungan energi dalam batuan dan fluida pada keadaan/kondisi awal $(\mathrm{kJ})$

$\mathrm{H}_{\mathrm{ef}}$ : kandungan energi dalam batuan danfluida pada keadaan kondisi akhir $(\mathrm{kJ})$

$\mathrm{H}_{\text {th: }}$ energi panas bumi maksimum yang dimanfaatkan $(\mathrm{kJ})$

$\mathrm{H}_{\text {de }}$ energi panas bumi maksimum yang dapat diambil ke permukaan $(\mathrm{kJ})$

$\mathrm{H}_{\mathrm{re}}$ : cadangan panas bumi yaitu energi panas bumi maksimum yang dapat di ambil ke permukaan selama perioda tertentu (MWth)

$\mathrm{H}_{\mathrm{el}} \quad$ potensi listrik panas bumi (MWe)

$\mathrm{R}_{\mathrm{f}} \quad$ faktor perolehan (fraksi)

$\mathrm{t}$ : lama waktu pembangkitan listrik (th)

$\eta ́$ : faktor konversi listrik (fraksi)

\section{Hasil dan Pembahasan}

3.1. Angka Parameter pada Kelas Sumber Daya Speku-latif, penentuan angka parameter ini yang di-asumsikan adalah rapat daya $\left(\mathrm{MWe} / \mathrm{km}^{2}\right)$ diambil dari data temperatur lapangan panas bumi yang ada, sedangkan parameter luas daerah $\left(\mathrm{km}^{2}\right)$ ditentukan dari data survey geologi.

\subsection{Angka Parameter pada Kelas Sumber Daya} Hipotesis, dasar parameter dalam kelas ini harus diten-tukan menggunakanasumsi dengan alasan sebagai berikut :

- Tebal reservoir, berupa ketebalan ratarata reservoir lapangan yang sudah berproduksi.

- Harga saturasi air dengan asumsi lapangan panas bumi di-dominasi air.

- Porositas rata-rata batuan vulkanik

- Kapasitas panas batuan berupa asumsi.

- Densitas rata-rata batuan panas bumi

- Umur pembangkitan listrik dari ratarata umur ekonomis pembangkitan listrik.

- Faktor konversi listrik ditentukan berdasarkan kemungkinan kehilangan energi panas setelah ditransfer ke dalam energi listrik lihat Tabel 1.
Tabel 1. Asumsi Angka Parameter pada Kelas Sumber Daya Hipotesis

\begin{tabular}{|l|c|c|c|}
\hline \multicolumn{1}{|c|}{ Parameter } & $\begin{array}{c}\text { Temp. Tinggi } \\
\left(>225^{\circ \mathrm{C}}\right)\end{array}$ & $\begin{array}{c}\text { Temp. Tinggi } \\
\left(125-225^{\circ \mathrm{C}}\right)\end{array}$ & $\begin{array}{c}\text { Temp. Tinggi } \\
\left(<225^{\circ \mathrm{C}}\right)\end{array}$ \\
\hline Tebal Reservoir $(\mathrm{m})$ & 2000 & 2000 & 2000 \\
\hline Saturasi air $(\%)$ & 100 & 100 & 100 \\
\hline Porositas Batuan (\%) & 10 & 10 & 10 \\
\hline Kapasitas Panas Batuan (kJ/ $\left./ \mathrm{kg}^{\circ \mathrm{C}}\right)$ & 1 & 0.9 & 0.8 \\
\hline Umur Pembangkitan (tahun) & 30 & 30 & 30 \\
\hline Faktor Konversi Listrik (\%) & 10 & 10 & 10 \\
\hline
\end{tabular}

\subsection{Angka Parameter pada Kelas Cadangan} Terduga, parameter dalam kelas ini harus ditentukan dengan asumsi dan dasar penentuan angka parameter kelas ini ditentukan dengan alasan yang sama dengan kelas sumber daya hipotesis diatas, tanpa Tebal Reservoir (Tabel 2).

Tabel 2. Asumsi Angka Parameter pada Tingkat Cadangan Terduga

\begin{tabular}{|l|c|c|c|}
\hline \multicolumn{1}{|c|}{ Parameter } & $\begin{array}{c}\text { Temp. Tinggi } \\
\left(>225^{0 \mathrm{C}}\right)\end{array}$ & $\begin{array}{c}\text { Temp. Tinggi } \\
\left(125-225^{\circ \mathrm{C}}\right)\end{array}$ & $\begin{array}{c}\text { Temp. Tinggi } \\
\left(<225^{\circ \mathrm{C}}\right)\end{array}$ \\
\hline Saturasi air (\%) & 100 & 100 & 100 \\
\hline Porositas Batuan (\%) & 10 & 10 & 10 \\
\hline Kapasitas Panas Batuan (kJ/kg $\left.{ }^{0 \mathrm{C}}\right)$ & 1 & 0.9 & 0.8 \\
\hline Densitas Batuan (kg/m $\left.\mathrm{m}^{2}\right)$ & $2.50 \times 10^{3}$ & $2.60 \times 104$ & $2.70 \times 105$ \\
\hline Umur Pembangkitan (tahun) & 30 & 30 & 30 \\
\hline Faktor Konversi Listrik (\%) & 10 & 10 & 10 \\
\hline
\end{tabular}

3.4. Parameter pada kelas cadangan mungkin, seperti terlihat pada Tabel 3, harga parameter kelas ini ditentukan dengan pengukuran atau pengambilan data yang dilakukan langsung di lapangan dan kemudian dianalisis di laboratorium secara detil seperti: luas, ketebalan reservoir, saturasi air, porositas batuan, kapasitas panas batuan, densitas batuan dan densitas air.Harga parameter yang menggunakan asumsi adalah:

- Umur atau lama pembangkitan listrik.

- Faktor konversi listrik pada kemungkinan rata-rata

kehilangan energi di dalam transfer energi panas menjadi energi listrik

\subsection{Angka Parameter pada Kelas Cadangan} Terbukti, harga parameter dalam kelas ini secara detil telah dijelaskan di Kelas Cadangan Mungkin, seperti terlihat pada Tabel 3.Perlu diperhatikan bahwa harga parameter yang digunakan pada Kelas ini ditentukan pada saat kondisi sumur panas bumi telah dilakukan program delineasi dan peng-embangan serta dilakukan studi kelayakan. 
Tabel 3. Asumsi Angka Parameter pada Tingkat Cadangan Mungkin dan Terbukti

\begin{tabular}{|c|c|c|c|}
\hline Parameter & $\begin{array}{l}\text { Temp. Tinggi } \\
\left(>225^{\circ C}\right)\end{array}$ & $\begin{array}{l}\text { Temp. Tinggi } \\
\left(125-225^{\circ C}\right)\end{array}$ & $\begin{array}{l}\text { Temp. Tinggi } \\
\left(<225^{\circ C}\right)\end{array}$ \\
\hline Luas $\left(m^{2}\right)$ & \multirow{7}{*}{$\begin{array}{l}\text { Pengukuran } \\
\text { dilakukan } \\
\text { langsung di } \\
\text { lapangan dan } \\
\text { laboratorium }\end{array}$} & \multirow{7}{*}{$\begin{array}{l}\text { Pengukuran } \\
\text { dilakukan } \\
\text { langsung di } \\
\text { lapangan dan } \\
\text { laboratorium }\end{array}$} & \multirow{7}{*}{$\begin{array}{l}\text { Pengukuran } \\
\text { dilakukan } \\
\text { langsung di } \\
\text { lapangan dan } \\
\text { laboratorium }\end{array}$} \\
\hline Ketebalan Reservoir (m) & & & \\
\hline Saturasi air (\%) & & & \\
\hline Porositas Batuan (\%) & & & \\
\hline Kapasitas Panas Batuan $\left(\mathrm{kJ} / \mathrm{kg}^{0 \mathrm{C}}\right)$ & & & \\
\hline Densitas Batuan $\left(\mathrm{kg} / \mathrm{m}^{2}\right)$ & & & \\
\hline Densitas Air $\left(\mathrm{kg} / \mathrm{m}^{3}\right)$ & & & \\
\hline Umur Pembangkitan (tahun) & 30 & 30 & 30 \\
\hline Faktor Konversi Listrik (\%) & 10 & 10 & 10 \\
\hline
\end{tabular}

\subsection{Parameter Data Dalam Estimasi Cadangan Dan Potensi Listrik Panas Bumi Lapangan "X"}

Perhitungan estimasi cadangan dan potensi energi panas bumi di Lapangan " $\mathrm{X}$ " membutuhkan 2 (dua) parameter fisis, yaitu:

1. Parameter tetap, diperoleh dari data asumsi yaitu:

- Faktor konversi listrik sebesar 10\% dan

- Umur pembangkitan selama 30 tahun.

2. Parameter variable, diperoleh dari hasil pengolahan data lapangan sumur Eksplorasi SAKA-1 (Lihat bagan alir Gambar 3). terdiri dari;

- Luas Area Prospek, sistem panas bumi "X" ber-hubungan dengan gunungapi tidak aktif atau post volcanic activity dan dari bawah kelurusan kerucut-kerucut muda, yang diperkirakan dikontrol sepasang sesar dengan arah barat laut-tenggara, sebagai jalur perpindahan panas. Luas area prospek berdasarkan sebaran batuan yang yang mempunyai tahanan jenis semu rendah (< $10 \Omega \mathrm{m})$ pada peta tahanan jenis semu $\mathrm{AB} / 2=1000 \mathrm{~m}$, yaitu $5 \mathrm{~km}^{2}$ dengan perincian daerah Watu-wawer sekitar 4.5 $\mathrm{km}^{2}$ dan Lewokebingin sekitar $0.5 \mathrm{~km}^{2}$. (Gambar 2).

- Ketebalan Lapisan Prospek, lapisan lebih resistif bernilai 12,26 - 17,7 $\Omega \mathrm{m}$ sebagai lapisan reservoir. Top reservoir berada pada kedalaman $900 \mathrm{~m}$, dengan tebal lapisan reservoir $2000 \mathrm{~m}$. Sedangkan ketebalan lapisan batuan tudung dengan tahanan jenis rendah bernilai 1,55 - 10,0 $\Omega \mathrm{m}$ adalah lapisan $600-800 \mathrm{~m}$.

- Volume Batuan, dihitung dengan mengalikan luas sebaran dan ketebalan batuan reservoir sebesar $10.10^{6} \mathrm{~m}^{3}$
- Estimasi Temperatur bawah permukaan, Data sumur SAKA-1 digunakan sebagai pengukuran temperatur reservoir lapangan panas bumi " $\mathrm{X}$ " pada kedalaman $830,5 \mathrm{~m}$. Hasil pengukuran temperatur dengan pemanasan selama 14,5 jam di masing-masing interval kedalaman yakni 0 $-196 \mathrm{~m}\left(70^{\mathrm{oC}}\right), 0-252 \mathrm{~m}\left(112,7^{\circ \mathrm{C}}\right)$ dan $502 \mathrm{~m}\left(201^{\mathrm{oC}}\right.$ dan dari ekstrapolasi diperoleh temperatur sebesar $118^{\circ \mathrm{C}}$ dan $220^{\circ \mathrm{C}}$ untuk kedalaman $252 \mathrm{~m}$ dan $502 \mathrm{~m}$, dengan gradien temperatur sebesar $36^{\circ \mathrm{C}} / 100$ dan $32^{\circ \mathrm{C}} / 100 \mathrm{~m}$ pada kedalaman $252^{\circ \mathrm{C}}$ dan $502 \mathrm{~m}$. Data temperatur sumur keadaan akhir sumur SAKA-1 pada zona reservoir, dengan selisih temperatur masuk / keluar antara $10-12,5^{\circ \mathrm{C}}$ dan korelasi temperatur adalah $3-3,5$ dikalikan temperatur lumpur keluar. Sehingga temperatur lubang sumur SAKA-1 adalah berkisar antara 3,5 "X" 71,5 yaitu 214,5 $250^{\circ \mathrm{C}}$

- Saturasi Air dan Saturasi Uap, adalah 0.3 dan 0.7

- Porositas Batuan, pada lapangan ini sebesar $10 \%$.

- Densitas Batuan dan air $\left(\rho_{\mathrm{L}}\right), 2500 \mathrm{~kg} / \mathrm{m}^{3}$ dan $798 \mathrm{~kg} / \mathrm{m}^{3}$ 8. Panas spesifik batuan $\left(\mathrm{C}_{\mathrm{r}}\right): 1 \mathrm{~kJ} / \mathrm{kg}$.

- Suhu awal reservoir $\left(\mathrm{T}_{\mathrm{i}}\right): 250^{\circ} \mathrm{C}$

- Energi dalam air $\left(\mathrm{U}_{\mathrm{L}}\right): 1082 \mathrm{~kJ} / \mathrm{kg}$

- Panas Batuan dan Fluida, panas dalam reservoir

Data kondisi akhir :

1. Temperatur akhir : $180^{\circ \mathrm{C}}$

2. Tekanan akhir : 10 bar, air menjadi uap

3. Saturasi uap (Sv) : $0.7 \%$

4. Energi dalam uap (Uv) : $2602 \mathrm{~kJ} / \mathrm{kg}$

5. Densitas uap ( $\rho v): 20 \mathrm{~kg} / \mathrm{m} 3$

6. Recovery Factor (RF) : $25 \%$

\subsection{Perhitungan Estimasi Cadangan Dan Potensi Panas Bumi Dengan Metoda Volumetrik}

Metode volumetrik dengan menggunakan parameter fisik tersebut diatas dan faktor perolehan (recovery factor) sebesar 25\%

Panas yang tersimpan dalam batuan :

$\mathrm{Qr}=$ A.h. $(1-\Phi) \cdot \operatorname{pr} \cdot \mathrm{cr} \cdot \mathrm{T}=5 \cdot 63 \cdot 10^{12} \mathrm{KJ}$

Sehingga Panas yang tersimpan dalam fluida: Qe $=$ A.h. $\Phi \cdot\left(\mathrm{S}_{\mathrm{L}} \cdot \rho_{\mathrm{L}} \cdot \mathrm{U}_{\mathrm{L}}+\mathrm{Sv} \cdot \rho \mathrm{\rho v} \cdot \mathrm{Uv}\right)=2.95459 \cdot 10^{12} \mathrm{KJ}$

Energi panas di dalam batuan dan fluida reservoir: $\mathrm{He}=$ A.h. $\left[(1-\Phi) \cdot \rho r \cdot c r . T+\Phi \cdot\left(S_{L} \cdot \rho_{L}\right.\right.$ "X" $U_{L}+$

Sv.pv.Uv)]

$\mathrm{He}=5.30774 .10^{12} \mathrm{KJ} / \mathrm{kg}$. 
Energi panas yang dikandung dalam batuan dan fluida pada kondisi awal :

$\mathrm{H}_{\mathrm{e}}=6,24831.10^{12} \mathrm{KJ}$

Energi panas yang dikandung dalam batuan dan fluida pada kondisi akhir :

$\mathrm{H}_{\mathrm{ef}}=4,67331 \cdot 10^{12} \mathrm{KJ}$

Perhitungan energi panas maksimum yang dapat dimanfaatkan pada lapangan "X" dilakukan dengan cara:

$\mathrm{H}_{\mathrm{th}}=\mathrm{H}_{\mathrm{ei}}+\mathrm{H}_{\mathrm{ef}}=1,575.10^{12} \mathrm{KJ}$.

Sehingga didapatkan estimasi cadangan panas bumi atau energi panas bumi yang kenyataannya dapat diambil, dengan memasukkan factor rekoveri (RF) sebesar:

$\mathrm{H}_{\mathrm{de}}=3,94.10^{11} \mathrm{KJ}$

Dan jika cadangan dinyatakan dalam satuan $\mathrm{MW}_{\text {th }}$, maka besar cadangan panas bumi adalah :

$\mathrm{H}_{\text {th }}=4.1391 .10^{17} \mathrm{MW}_{\text {th. }}$.

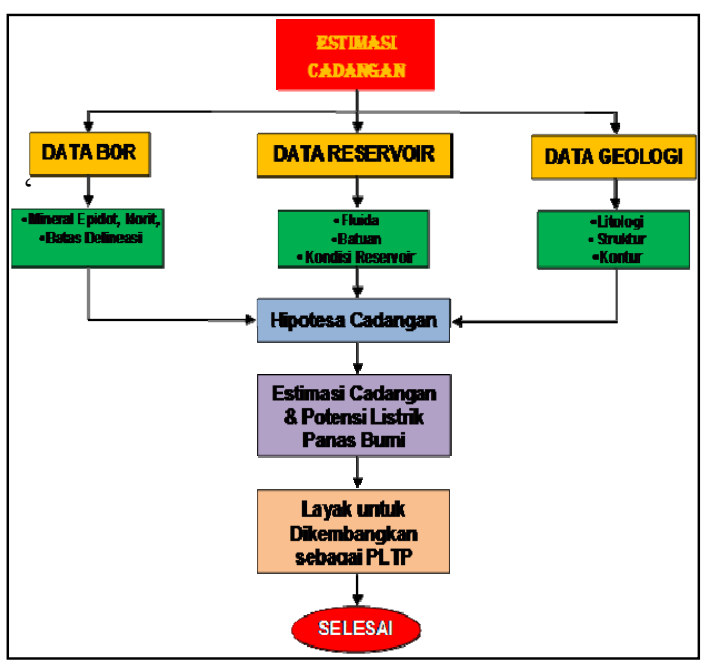

Gambar 3. Bagan Alir Estimasi Cadangan Dan Potensi Panas Bumi

Selanjutnya besarnya potensi listrik panas bumi $\left(\mathrm{MW}_{\mathrm{e}}\right)$ yang dapat dibangkitkan adalah mengkalikan cadangan panas bumi dengan faktor konversi listrik dan dibagi dengan lamanya waktu kontrak selama 30 tahun maka didapatkan hasil sebesar:

$\mathrm{H}_{\text {thermal }}=4,1.10^{16} \mathrm{MW}_{\mathrm{th}}=41 \mathrm{Mw}_{\mathrm{e}}$.

\section{Kesimpulan}

1. Cadangan energi panas bumi yang kenyataannya dapat diambil adalah 3,94 "X" $10^{11} \mathrm{~kJ}$ dan besarnya potensi listrik yang dapat dibangkitkan pada lapangan panas bumi " $X$ " adalah sebesar 41 Mwe.

2. Lapangan panas bumi " $X$ " prospek untuk dikembangkan sebagai Pembangkit Listrik Tenaga Panas Bumi (PLTP), sehingga kebutuhan listrik masyarakat Kabupaten Lembata sebesar 5 Mwe dapat terpenuhi dengan tersedianya cadangan sebesar 41 Mwe.

\section{Daftar Pustaka}

Badan Standarisasi Nasional, "Angka Parameter Dalam Estimasi Potensi Energi Panas Bumi”, SNI, 13-6482-2000.

Badan Standarisasi Nasional, "Klasifikasi Potensi Panas bumi di Indonesia, SNI, 13-5012-1998.

Departemen Energi dan Sumber Daya Mineral, Badan Geologi. 2006. "Inventarisasi dan Penyelidikan Bahan Galian non Logam di Kabupaten Lembata”, Bandung.

Direktorat Inventarisasi Sumber Daya Mineral. 2003. "Report kegiatan prastudi kelayakan daerah panas bumi Atalojo “ $X$ ”, Bandung.

Direktorat Inventarisasi Sumber Daya Mineral. 2004. "Laporan Pemboran Sumur Esplorasi Lapangan panas bumi " $X$ ” Kabupaten Lembata Nusa Tenggara Timur”, Bandung.

Direktorat Inventarisasi Sumber Daya Mineral. 2004. "Laporan Pemboran Sumur Esplorasi Lapangan panas bumi " $X$ ” Kabupaten Lembata Nusa Tenggara Timur”, Bandung.

Nanlohy Fredy., Kusnadi Dedi., Sundhoro Herry.2003. Makalah, "Program pengembangan lapangan panas bumi " $X$ " Kabupaten Lembata - NTT “, Subdit Panas bumi, Bandung.

Septadji Nenny Miryani,PhD. 1990. “Teknik Panas Bumi”, ITB, Bandung.

Amyx, J.,W Bass, DW. Jr., Whiting, R, L., "Petroleum Reservoir Engineering Physical Properties", Mc Graw Hill Books Company, New York, Toronto, London, 1660.

Crichlow, H..B, "Modern Reservoir Engineering A Simulation Approach", Prentice-Hall, Inc., Englewood Cliffs, New Jersey, 1977.

Craf, B.C ang Hawkins, M.. F. "Applied Petroleum Reservoir Engineering "Prentice-Hall, Inc., Englewood Cliffs, New Jersey, 1959.

Craig, J.R., F.F., Geffen, T.M. Morse R.A. "Enhanced Oil Recovery", SPE Textbook Series Volume 6, Texas, 1998.

Koesumadinata, R.P.,Geologi Minyak dan Gas Bumi. Jilid I dan II, Edisi Kedua, Jurusan Teknik Perminyakan ITB, Bandung, 1980.

Lee, W.J., “Applied Reservoir Simulation Industry School" Simulation Course Handbook, Texas A\&M University, June, 1995. 
Potensi Cadangan Panas Bumi dengan Metoda Volumetrik Pada Sumur Saka-1 Lapangan Panas Bumi “X” Kabupaten Lembata NusaTenggara Timur

Mattax, C.C and Dalton, R.L., "Reservoir Simulation" Society of Petroleum Engineers Inc, Texas, 1990.

..............., "Advance Compositional Reservoir Simulation Version 2006" GEM User Guide Computer Modelling Group. Ltd.,2006.

"TAC Ranya Energi Pamanukan Selatan", 2006.

.............., "Practical Reservoir Simulation" Chevron Extended Aplication Reservoir Simulator User Handbook, Chevron Tech, Co., 1996. 